\title{
FROM EXCLUSIVISM TO PLURALISM: SHIFTING PERSPECTIVE OF THE GEREJA PROTESTAN MALUKU (GPM) IN INTERRELIGIOUS RELATIONS
}

\author{
Rachel Iwamony \\ Faculty of Theology Universitas Kristen Indonesia Maluku \\ Jalan Ot Pattimaipauw Talake, Kecamatan Nusaniwe Kota Ambon, Maluku, Indonesia \\ E-mail: racheliwamony07@gmail.com
}

\begin{abstract}
This article aims to find out and describe the shifting position of the GPM (Gereja Protestan Maluku) as to other religions, especially Islam. Through library research towards some important documents of the GPM, the researcher found out the development of theological perspectives of the GPM which are fundamental and important for the GPM in understanding other religions. In studying these documents, this study discovered that the position of the GPM as to other religions before the social conflict in 1999 and 2004 are differ significantly to that of after the social conflict. In the document of PIP/RIPP in the period of 1995 to 2005, before the social conflict, they described clearly that the GPM recognizes other religions as the object of its mission. In contrast, in the same document of the period of 2005 to 2015 , after the social conflict, they state that the GPM embraces other religions as its partner. Even in the newest document of Ajaran Gereja GPM, they state that God in Jesus Christ is the Savior of all human beings without religious categories. These theological notions have a significant impact on the GPM in shaping its relation with other religions. Not only the theological normative notion, but also the cultural perspectives such as Pela have opened the possibility for the Moluccan Moslems and Christians to coexist as brothers and sisters.
\end{abstract}

Keywords:

Religion; Theology; Church; Christianity; Transformation.

\begin{abstract}
Abstrak
Artikel ini ditulis untuk menemukan dan menggambarkan perkembangan penerimaan Gereja Protestan Maluku terhadap agama lain, secara khusus agama Islam. Dengan melakukan studi kepustakaan terhadap beberapa dokumen penting dari GPM, ditemukan perkembangan pemikiran teologis yang sangat mendasar dan berarti bagi GPM dalam melihat agama-agama lain. Dari dokumen-dokumen tersebut, ditemukan bahwa sikap yang dimiliki oleh GPM terhadap agama lain berbeda sebelum dan sesudah konflik sosial di Maluku pada tahun 1999 dan 2004. Dari dokumen PIP/RIPP GPM tahun 1995 - 2005 yang dihasilkan sebelum konflik sosial, tergambar sikap penolakan terhadap agama-agama lain; sebaliknya, dokumen PIP/RIPP GPM tahun 2005 - 2015 yang dihasilkan sesudah konflik menunjukkan sikap penerimaan terhadap agama-agama lain. Bahkan dalam dokumen Ajaran Gereja GPM, ditegaskan bahwa Allah di dalam Yesus Kristus menyelamatkan seluruh umat manusia, apapun agamanya. Cara pandang seperti ini sangat mempengaruhi GPM dalam membangun hubungannya dengan agama-agama lain. Perubahan cara pandang GPM terhadap agama lain dipengaruhi oleh keterbukaan gereja untuk belajar dari budaya lokal, seperti budaya Pela yang telah membuka ruang bagi penganut agama Islam dan penganut agama Kristen untuk hidup sebagai orang bersaudara, tanpa mengingkari kekhasan imannya.
\end{abstract}

\author{
Kata Kunci: \\ Agama; Teologi; Gereja; Kekristenan; Transformasi.
}




\section{A. INTRODUCTION}

Gereja Protestan Maluku (abbreviated GPM) or the Protestant Church in the Moluccas is a church institution in the MoluccasIndonesia. As a religious institution, the GPM involves working on religious reconciliation which is needed in this contemporary context. Nowadays, harmonious religious relation becomes an important issue on earth because there are many religious social conflicts in society. People tend to reject other religious affiliations that differ from their own. For example, the case of the Gereja Kristen Indonesia (abbreviated GKI) or the Indonesia Christian Church, a church in Jakarta on January $12,2019,{ }^{1}$ the case of Pura at Bekasi on May 4th, 2019, ${ }^{2}$ rejecting of the construction of the Santa Clara church at Bekasi, ${ }^{3}$ rejecting of renovation of al-Aqsa Agung Mosque at Sentani, Papua, ${ }^{4}$ and a case in Tolikara Papua in $2015 .^{5}$ Those facts depict a way of thinking of religious majority versus minority. ${ }^{6}$ Christian majority in a certain places in Indonesia reject and tend to take control over Moslems minority and vice versa. Ironically, according to Muhammad Sabri and Sitti Musyahidah, all religions see the others in double standards perspective. They consider their own religion as the only true religion; while, others as false religions. ${ }^{7}$ Especially so

${ }^{1}$ Haris Prabowo, "Duduk Perkara Penolakan Gereja GKI Di Jagakarsa, Jakarta Selatan,” Tirto, accessed May 7, 2019, https://tirto.id/duduk-perkara-penolakan-gerejagki-di-jagakarsa-jakarta-selatan-deoZ.

${ }^{2}$ Alfian Putra Abdi, "Duduk Perkara Penolakan Pembangunan Pura Di Bekasi," Tirto, accessed May 7, 2019, https://tirto.id/dJez.

${ }^{3}$ Tempo.co, "Massa Berunjuk Rasa Tolak Pembangunan Gereja Santa Clara Bekasi," Tempo.co, $\begin{array}{llll}\text { accessed } & \text { May 2019, }\end{array}$ https://metro.tempo.co/read/859291/massa-berunjukrasa-tolak-pembangunan-gereja-santa-clara-bekasi.

${ }^{4}$ Mufti Sholih, "Di Balik Polemik Penolakan Menara Masjid Di Papua," Tirto, accessed May 7, 2019, https://tirto.id/di-balik-polemik-penolakan-menaramasjid-di-papua-cGrd.

${ }^{5}$ Moh Rosyid, "Peredam Konflik Agama: Studi Analisis Penyelesaian Di Tolikara Papua 2015," Afkaruna: Indonesian Interdisciplinary Journal of Islamic Studies 13, no. 1 (2017): 48-81. is related to religious symbols such as Mosque and church buildings that mostly become a provocative issue. ${ }^{8}$ Jamaluddin further reports that if someone narrowly understands religion, one tends to be intollerant to others and thus, religion falls into subjective matters. ${ }^{9}$ These are serious problems in religious life in Indonesia, especially when it comes to the rights of Indonesian citizen to live their beliefs freely.

Some intolerant cases in Indonesia are a warning to create harmonious religious life by working together among religious adherents and learning to respect each others. This is not an easy task to do as each religion has their own theological perspective towards others. Aisyah in her article entitled Konflik Sosial Dalam Hubungan Antar Umat Beragama stresses that religious truth claim has been the main reason of interreligious conflict. ${ }^{10}$ Another problem is the terms used in a negative impression about other religions such as 'heaven religion and earth religion.' 11 These are some important facts that challenge all religions to evaluate their theological point of view about others to reconcile one another. Precisely, religious reconciliation has become an important thing that all religions must do. ${ }^{12}$

As a part of the society that has poor experience about religious social conflict, the GPM takes part in the process of religious

${ }^{6}$ Rachel Iwamony, "Majority versus Minority," in International Conference on Religion and Public Civilization (ICRPC 2018) (Atlantis Press, 2019).

${ }^{7}$ Muhammad Sabri and Siti Musyahidah, "Agama Mainstream, Nalar Negara Dan Paham Lintas Iman: Menimbang Philosophia Perennis," Jurnal Diskursus Islam 3, no. 1 (2015), 77.

${ }^{8}$ Adon Nasrullah Jamaludin, "Konflik Dan Integrasi Pendirian Rumah Ibadah Di Kota Bekasi," Jurnal SocioPolitica 8, no. 2 (2018): 228.

${ }^{9}$ Jamaludin, "Konflik Dan Integrasi Pendirian Rumah Ibadah Di Kota Bekasi."

${ }^{10}$ B M St Aisyah, "Konflik Sosial Dalam Hubungan Antar Umat Beragama," Jurnal Dakwah Tabligh 15, no. 2 (2014), 196.

${ }^{11}$ Frans Magnis-Suseno, Iman Dan Hati Nurani (Jakarta: Yayasan Obor, 2014), 23.

${ }^{12}$ Rachel Iwamony and Tri Astuti Relmasira, "Rekonsiliasi Sebagai Proses Bersama Menyembuhkan Luka Sejarah Islam Kristen Di Kota Ambon," Religió: Jurnal Studi Agama-Agama 7, no. 1 (2017), 15-16. 
reconciliation. It is a challenging task for the GPM because it faces a society that runs their daily life in a religious-based segregation settlement. ${ }^{13}$ Based on that context, the research problem of this study is how the GPM understand other religions and the theological positions of the GPM towards other beliefs. This study employs qualitative method with document analysis to the development of GPM church's theological position towards others.

\section{B. RESULTS AND DISCUSSION}

Historically, the GPM had a great impact on how this congregation runs its mission in Moluccas Indonesia, including its position as to other religions. Therefore, talking about the position of the GPM as to other religions, this article will briefly describe how the GPM come into existence; explain the GPM's theological position before and after $2005 ;{ }^{14}$ and finally, describe how the Pela has shaped the religious life of the Moluccans.

Pela is a Moluccans' local custom in which some people performed to overcome crises such as the local war between villages or help villages recovering from a natural disaster. In each situation, villages declared themselves as brothers and sisters. By having Pela, they recognized some basics obligation between each other such as giving help regardless of religion or ethnic. In some Pela relationship, especially the ones called Pela Darah (blood Pela), members of those villages are prohibited to marry their members with other members from different villages. ${ }^{15}$

\section{Brief History of the Existence of the GPM}

The GPM was one of the State Church members in Indonesia. Many scholars have written about the nature of the State Church. However, this study focus on how the State
Church influenced the life of Moluccan Christians and Muslims.

The Dutch Constitution has inspired the existence of the State-Church in the Netherlands as well as in Dutch collonialization in Indonesia. Under the Constitution of 1830, the King was declared to be the head of all churches in his domain. One of his great aims was gathering of all Protestant adherents into one church. ${ }^{16}$ Neil writes that "the King assumed himself to be no less dictator of the missionary societies that of the Churches organized for the Dutch residents and their dependents. He claimed the right to appoint, locate, and withdraw missionaries at his good pleasure." ${ }^{17}$ Based on this policy all of the Protestant Churches in Indonesia were united into one organization called the Protestant Church in Hindia Belanda (Indonesia) or Gereja Protestan Indonesia (abbreviated GPI). ${ }^{18}$ Protestantism in the Moluccas or the GPM became one of these united churches.

However, this situation negatively encouraged the State to take a strong position inside the Christian Church, more so than in the other religious communities in Indonesia. This view was contradicted with the thought that religion was outside of the state's control or that the state must be neutral to all religions. In this regard, Van den End offers two possible answers. First, some congregations had been established during the Dutch East-India Company or Vereenigde Oostindische Compagnie (abbreviated VOC) period. The state could not leave these congregations. Second, the State had recognized that the Muslims tended to resist the Dutch authority more rather than the Christians. Thus, all pagans in Indonesia must become Christians

\footnotetext{
${ }^{16}$ Stephen Neill, Colonialism and Christian Mission (London: Lutterworth Press, 1966), 188.

${ }^{17}$ Stephen Neill, Colonialism, 188-189.

${ }^{18}$ Th. van den End, Ragi Carita 1 (Jakarta: BPK Gunung Mulia, 2001), 146.
} 
instead of becoming Muslims."19 Because of these two reasons, the GPI came to the surface and has been existed until now.

One of the main characters of the State Church was that the head of the church's officers had a high position in the government. ${ }^{20}$ This also happened during the VOC period when the church became one of its departments. This situation provided better opportunities for the Moluccan Christians rather than the Moluccan Muslims. Moluccan Christians received a good education because it was an integrated part of the mission activities of NZG (Nederlansche Zendeling GenotschapDutch Missionary Foundation) as well as the GPI. Furthermore, Moluccan Christians have special opportunities to become part of the military force which was not available to Muslims. Since many Moluccan Christians were well-educated, they had better opportunities to work in government offices. In contrast, the Moluccan Muslims tended to work in business and became successful businessmen. In other words, these phenomena proved that there were inequal rights for people living in the same region. During this period, the State discriminated its citizens based on their religious background. How did the church understand this discrimination? Did the church realize that such phenomena contradicted the Christian doctrin and faith? In this case, this study assumes that the church did not see any discrimination in their social life because it was a way to pursue missions in the domain.

Another character of the State-Church relationship was when the state has full control of the churches within its domain. It hurts the churches "because the state wants all Christian Protestants to be united into one church, therefore, the state does not see a need for the church to have a confession." 21 The Christian Protestants in the Moluccas have been implementing this policy, even though they are now an independent church. The GPM did not have its confession until 2005. Some Dutch scholars did not see any positive aspect of the existence of a State-Church in Indonesia. After visiting Minahasa and the Moluccas, Hendrik Kraemer describes what he saw in such places as follows:

As an organization, the Protestant Church in the Indies originates from a government decision. It is wholly part of the government in a twofold sense. The appointment and defrayment of its ministers always emanate from the government, and its organization and administration have been modelled upon and fitted into the government system.... The inevitable conclusion to be drawn from the definition above: because the Protestant Church has been conceived in centralist bureaucratic and secular official terms, its basic conception is unChristian and un-Protestant... It is a government institution for spiritual care carrying out the task with the means usually employed by Protestant Churches in general. Without this government, which in principle does not care about life or doctrine in so far as it is outside the Penal Code, the protestant Church in the Indies will collapse as an institution. ${ }^{22}$

From the above statements, Kraemer stated that the State-Church did not reflect what the Church was. It was only a servant of the government. Therefore the church could not perform its mission properly. However, there is a lack of answers about this. It is worthy to say that van den End said that the state favoured the church to keep itself in power. Yet, at the same time, it leads to marginalize or alienate Muslims Moluccans. ${ }^{23}$

\section{Being an Independent Church with a Special Character}

\footnotetext{
${ }^{19}$ Th. van den End, Ragi, 145.

${ }^{20}$ Th. van den End, Ragi, 146.

${ }^{21}$ Th. van den End, Ragi, 147.

22 Stephen Neill, Colonialism, 189; see also Hendrik Kraemer, From Missionfield to Independent Church:
}

\author{
Report on a Decisive Decade in the Growth of \\ Indigenous Churches in Indonesia (Zoetermeer: \\ Boekencentrum, 1958), 31-36. \\ ${ }^{23}$ Th. van den End, Ragi 1, 150.
}


Many factors were influencing the Protestant Church in Indonesia or the GPI in the Moluccas to be an independent church in September 1935. Van den End and Weitjens ${ }^{24}$ note that there are three factors regarding the independence of the churches as follows:

a. The Protestant Church in Indonesia paid more attention to maintain the faith of its members, especially Indonesian Christians. The GPI was aware of its responsibility to the nurture faith of its members. Therefore, having more independent churches was imperative.

b. Schooling was separated from the Church, so that teacher in the school no longer take responsibility for the congregation. Since the period of the VOC, the GPI has a policy in which a teacher must also be a pastor at a local congregation. Therefore, the church faced many difficulties in providing its pastor.

c. Since the 1890 s there was a significant increase in membership of the Protestant Church. Thus, it became a challenge for the church to keep maintaining its congregation.

The above mentioned factors show that the situation in the life of the Christians in Indonesia and the Moluccas had forced the GPI to rethink about its approach to the church organization. The church must be organized to maintain the life of its members. Thus, the main motivation of GPI is to create an independent church as needed by local believers. However, this situation was also influenced by other factors. First, the financial problem faced by the Dutch government. Second, the nationalis movement in Indonesia challenged the Moluccans to seek an independent church. ${ }^{25}$ Among the Moluccans, W. H. Tutuarima must be mentioned as a minister who worked on

\footnotetext{
${ }^{24} \mathrm{Th}$ van den End and J. Weitjens, Ragi Carita 2:Sejarah Gereja Di Indonesia 1860-an - Sekarang (Jakarta: BPK Gunung Mulia, 1993), 59.

${ }^{25}$ Th van den End and J. Weitjens, Ragi 2, 70.

${ }^{26}$ The GPM, Tata Gereja Dan Peraturan-Peraturan Pokok Gereja Protestan Maluku (Ambon: The GPM, 1990), 7.
}

preparing local ministers. All these factors influenced the GPM to be an independent church.

The establishment of the GPM in September 6th 1935 was wider than today's Moluccas. Some places in Papua such as Fak-Fak was also serviced by the GPM. However, one has to acknowledge that the GPM is an ethnic Church. It is clearly stated in the Church Order that "the GPM is a congregation in the Moluccan Islands." ${ }^{26}$ This statement does not only refer to the territorial aspect of the organization, but also refers to an ethnic group. This ethnic church has positive and negative aspects. Positively, the GPM will serve its members contextually because most of its members have the same cultural root. Negatively, the GPM serves the people too regionally and exclusive.

In the Indonesian context, this condition does not help the GPM to do its task in proclaiming the gospel to Indonesian society. Because the institution of a church has been connected to a certain ethnicity, it is very difficult for the GPM to criticize the Indonesian government. The church's voice will be heard as an ethnic voice that wants to create national destabilization. To avoid this impression, the church needs to become a good partner of the Indonesian government. Another weakness is a difficultness to accommodate the believers who come from other ethnicities. It is even worse when in the spirit of contextualization; ${ }^{27}$ every ethnic group tries to create their liturgy, worship and song. Others will not feel included in church worship. They will be newly marginalized people in the lives of the believers. What will happen to the people who are only staying for a while in a place because of his/her job? Should they make their own congregations? Additionally, there are special characteristics of GPM Christianity. First,

${ }^{27} \mathrm{I}$ do not think negatively regarding contextualization, However, it must be done critically, so that it does not create a new problem in the life of the believers. 
because the church and Christian have been part of the Moluccan Christian traditions if one views Christian religion and the church negatively, people will react. Moreover, the Christian faith has been seen as part of their adat (customs), and consequently, they are not open to new ideas. They want to retain everything from past generations. Second, Christianity of the GPM is a collective or a communal faith. ${ }^{28}$ Thus, if one decides to leave his/her common faith he/she will receive a negative reaction. Some important questions for this church are: What does it mean to be an independent church? Is it only related to the structural or institutional purpose? Should this independent church also create an independent way of thinking about how Christianity in the Moluccas must establish its relation with other religions? In what way does independence give a positive contribution to the religious relationships in the Moluccas? An in-depth study is needed to answer these questions, and many possible answers might be found, but those are not intended of this study.

\section{Islam in the Perspective of Missionaries}

It should be noted that missionary activities whether Catholic or Protestant, Muslims were not seen as pagan or heathen. Missionaries always distinguished between the Muslims and the heathens when they described the local condition of a certain place in the Moluccas. ${ }^{29}$ However, there is a lack of answers about whether or not Christianity recognized Islam as a religion. Yet, we can assume that the Dutch government did not want to create problems with Muslims, so missionaries never did any work among Muslims. However, it is difficult to find a positive point in missionaries' perspective in understanding Islam. How Joseph Kam understood Muslim is an example. Kam had a negative impression of Islam. Enklaar describes that to convince the raja of Waisamu $^{30}$ to convert to Christianity, Kam told raja Waisamu that "our religion focused only on the Prophet, sent by God into this world who, after having acquired atonement for our sins by His suffering and death, has been raised into heaven, but that the Muslims comfort themselves by visiting the corpse of their prophet who was a sinful man like all of us and who therefore was confined to death." ${ }^{31}$ Also, Enklaar describes Kam's attitude when faced the Muslim in the following sentence:

Kam found it was difficult to create a genuine dialogue with Islam. He looked at them only in terms of a false prophet, false teachings, blind religion, etc. His method for winning Muslims to the Gospel was restricted to weak attempts to convince his opponents in an antithetical manner of the superiority of Christ and the Bible above Muhammad and the Koran. He spread also copies of the Holy Scriptures with the silent prayer in his heart that the light of revelation in this way might bring the stubborn souls of the 'Slammers' (colloquial for Muslims) to the knowledge of the truth. ${ }^{32}$

There are two ideas that this article attempts to stress related to Kam's perception of Muslims. First, Kam's motivation was winning

\footnotetext{
${ }^{30}$ Waisamu is a village located in Seram Island in the Moluccas-Indonesia.

${ }^{31}$ Ido Hendricus Enklaar and Joseph Kam, Apostel

Der Molukken (Zoetermeer: Boekencentrum, 1963), 132. See also C G F de Jong and M van Selm, "Verslag van Een Reis Naar de Zuidwester-En ZuidoosterEilanden (Zuid-Molukken) Door Joseph Kam (1825)," Documentatieblad Voor de Geschiedenis van de Nederlandse Zending En Overzeese Kerken 6 (1999): 47-78. See also Verry Patty, "Molukse Theologie in Nederland: Agama Nunusaku En Bekering" (Vrije Universiteit, 2018).

${ }^{32}$ Enklaar and Kam, Apostel Der Molukken, 132.
} Indigenous Churches in Indonesia, 20.

${ }^{29}$ When Langen informed the situation of Tual for Bishop Claessens, he writes that nearby Kei Kecil there are about 15,000 heathens and 800 Muslims. Based on this information, we can notice that missionary activities were needed in Tual because there were many heathens. See Karel Steenbrink, Catholics in Indonesia, 18081942: A Documented History. Volume 2: The Spectacular Growth of a Self Confident Minority, 19031942 (Leiden: Brill, 2007), 184. 
people to Christianity. To reach this goal he had no other way than to talk about the negative aspect of Islam. Second, the missionary activities of the church did not help the local people to understand the Christian faith without having to adopt a negative point of view regarding other religions, including Islam. In this way, only by recognizing the weakness of other religion could Christianity find its worth.

Even though Islam was not considered as pagan or heathen, relations between Christians and Muslims was not good. The negative tension between Muslims and Christians in the Moluccas has existed since the early period of Islamic and Christian missions to the area. In the book Sejarah Gereja Katolik Indonesia 1History of Indonesia Catholic Church-, there is an explanation that when the Portuguese came to the Moluccas, especially to Ambon Island, the northern and western Hitu had been Muslims and were the dire enemies of the Christian villages. ${ }^{33}$ In describing this situation, the author of the book comments that "the big enemies of the Christian religion live on the mountain slope. They are followers of the fanatic Prophet. By military force and support from Java, they pressed the heathen people and Christians in these islands to convert to Islam and to become their slaves." 34

It seems that the negative relationship existed among religions was also caused by the motivation of each to convert the other. Because of this motivation, Christians (both Catholic and Protestant) and Muslims were not afraid to take violence. Cooley writes about the religious violence in the Moluccas, "but in that time, the pressure of the Sultan Ternate had begun. Because of the Portuguese cruelty and his desire to spread Islam, Sultan Ternate attacked and destroyed the Portuguese fortress in Central Moluccas including many Christian villages. Many Christians were killed in this event." ${ }^{35}$ The negative relationship between
Christians and Muslims in the Moluccas is also noted by Van den End. He writes:

It was too fast for Christians in Ambon and Lease to show their loyalty for their new religion. The Crisis in 1557 and the following year was also happened in their region. Marines of Sultan Ternate came to Ambon. For three years Christians could only have a defense in one fortress in Mountain range. Besides, one can say that since 1558 there was continually guerilla war in Leitimor and Hitu, in Haruku and Saparua. Sometime Hitu was helped by Ternate or Java so that they were able to burn Christian's villages and forced Christians to leave their faith or to go to jungle; sometimes Christians were helped by the Portuguese. Consequently, Muslim villages were in a bad situation. ${ }^{36}$

Based on this information, one sees that religious sentiment encouraged people to come to a limited form of solidarity, such that religious sentiment was more important than ethnic solidarity. Religious people did not think about the dignity of human life. Thus, at this time all religions, whether Christian or Muslim, negatively impacted the lives of local people and prevented them from living peacefully.

However, in other places in the Moluccas, one could find that Muslims and Christians were able to live in relative peace. Kraemer takes note of some examples. He writes, "Sometimes Muslims give their children as a piara (foster-child) to Christians to enable them to go to school in a Christian kampong (village). In these cases, children were educated in an Islamic way by their Christian foster-parents, and they are protected from touching or eating pork." 37 Another example was a good relationship between Waai (a Christian village) and Tolehu (a Muslim village): ${ }^{38}$ "On Sunday a Mohammaden crowd will pass quietly through a

\footnotetext{
${ }^{35}$ Aritonang and Steenbrink, A History of Christianity in Indonesia.

${ }^{36}$ Th. Van den End, Ragi 1, 60-61.

${ }^{37}$ Kraemer, From Missionfield, 22.

${ }^{38}$ These two villages are located in Ambon island.
} 
Christian negorij (village), and a Christian will never carry a pig through an Islamic Negorij." $" 39$ After describing these facts, Kraemer offers his understanding of these good relationships. He says "These are all example of a pleasant and agreeable tolerance, which is rooted deeply based on family ties not based on religious conviction." 40 It is very clear, here, that these good relationships were based on local culture. Thus, it could be said that these good relationships were only among villages which have cultural relationships. Interestingly, Kraemer writes, "Some Christian Negorij, as a result of Christian preaching, show a willingness to proclaim the Gospel to the Muslims, or they would like to see Muslims embrace Christianity, but then preferably not in a nearby Negorij, because this would give rise to all sorts of Perkaras (problems)." ${ }^{41}$ It seems that a good relationship between Muslim and Christian in some places such as Waai and Tolehu was influenced by their local customs of respecting each other. They had also no rivalry in the past. On the contrary, villages that had bad relationship were local enemy to one another such as Leitimor and Hitu. These villages involved in conflict before being Muslim or Christians. Precisely, the situation was getting worse as religion contributes to strength the conflict.

\section{The GPM's Position Before and After the Social Conflict in Moluccas}

Talking about the position of the GPM before and after the social conflict happened in Moluccas between 1999 and 2004, this article refers to two important documents of the GPM, namely the Pola Induk Pelayanan dan Rencana Induk Pengembangan Pelayanan (abbreviated PIP/RIPP) or - the Chief Model of Ministry and Chief Plan of Developing the Ministry - and the GPM's Understanding of Faith.

The Chief Model of Ministry and Chief Plan of Developing the Ministry (PIP/RIP GPM) contain general policies for ministry, descriptions and strategies for the development of the GPM's programs and activities approved by the Synod Assembly. Their function is to regulate the practical activities of the church ministry through the annual programs. In the ministry strategies of the GPM, PIP and RIPP are tied together. Therefore, such documents should be read as a united document. This study will focus on the PIP/RIPP from 1995 to 2005 and that of 2005 to 2015, especially addressing Christian and Muslim relation.

\section{a. PIP/RIPP of 1995 to 2005}

In the PIP/RIPP of 1995 to 2005, the GPM did not speak specifically about how the church understands other religions. The church did refer to other religion, especially Islam in its understanding about the church itself. Interestingly, in understanding of its ecclesiology, the GPM still looks to the past church history. The GPM understand that the Christianity which exists in the Moluccas was influenced by western ecclesiology (point. 2.4). This had been seen as the main factor in understanding other religions, especially Islam (point. 2.8). In the explanation of this ecclesiological concept, many statements were made which expressed a form of repentance. The GPM confessed that "its member still lived the same way of life they lived before becoming Christians" (point. 2.5). Therefore, their attitudes toward their cultural relationships were very important (point. 2.7). For the GPM, these cultural relationships must be understood proportionally to the church's relationship to the gospel of the Kingdom of God (point. 2.6).

\section{b. PIP/RIPP of 2005 to 2015}

Compared to the PIP/RIPP of 1995 to 2005, there are some changed principles in the document of PIP/RIPP of 2005 to 2015. One fundamental change is related to religions and other faith. Under the theme Religions and other faith, the GPM states clearly that "Religions and other faiths are fully part of 
God's work. Based on this fact, we are called to create good communication and gather together in peaceful, respectful and harmonious ways. Other religions are not seen as rivals of the church. In addition, under the theme of the Kingdom of God and Religions, the GPM states that "All religions point to the same God." This is a new concept that is stated in the document. It is a different concept compared to those of the GPM's document in earlier version. To help readers understand it well, the content of these documents related to the position of the GPM as to other religions will be described in a short table 1 below.

Table 1 : Comparison of PIP/RIPP 1995-2005 and PIP/RIPP 2005-2015

\section{PIP/RIPP of 1995 to 2005}

The existence of the GPM in the Moluccas was influenced by western ecclesiology (point. 2.4). This had been seen as the main factor in understanding other religions, especially Islam (point. 2.8). The members of the GPM still lived the same way of life they lived before becoming Christians" (point. 2.5). Therefore, their attitudes toward their cultural relationships were very important (point. 2.7). For the GPM, these cultural relationships must be understood proportionally to the church's relationship to the gospel of the Kingdom of God (point. 2.6) PIP/RIPP of 2005 to 2015

In the Vision of the church's ministry, the GPM stated that:

"GPM wants to nurture quality believers who must have open and progressive attitudes, and work to defend all aspects of human life. Believers must also live in solidarity with others in the church's life as well as in the broader society."

In the Goals of the church's ministry, the church stated two things:

- To improve and to implement cooperation and dialogue with other religions

- To improve and to participate in ecumenical cooperation among churches and denominations

The second program of the GPM was called 'Inter-religious Dialogue and Monologue.' The goal of this program was:

- To counter "fanatic dogmatism, exclusivism and triumphalist attitudes in the congregation's life," and fanatic proselytism.

\section{c. GPM's Understanding of Faith}

In the document of the GPM's understanding of faith, the GPM specifically speak about how the church understands other religions. In this document, the GPM sees all religions as social realities as well as religious realities.

As social realities, the Church and Other Religions are called to develop the lives of their members and the life of the nation as well. The church and other religions are called to reconcile with each other, to open up to each other and to respect each other." In other words, GPM has recognized that respecting other religions will enable all religions to come to a place of openness and positive relationships with one another. However, this should not lead the Church and Other Religions to lose their religious identities. Each specific identity must be regarded as positive, constructive, and open to a relationship. This identity enables the Church and Other Religions to be inspectors of ethical and moral values for their 
members and for a society which still struggles for the welfare of all people. ${ }^{42}$

As social realities, the church and other religions are called to develop the life of their members and the life of the nation as well. For the GPM, in doing its missions, the church and other religions are called to reconcile, to open up and to respect each other. Precisely, the GPM has acknowledged that respecting other religions will enable all religions to have positive relationships with one another. However, this should not lead the church and other religions to lose their own religious identities. While calling for respecting each other, the GPM asks other religions to hold onto their specific identities. Each specific identity must be regarded as positive, constructive, and open to relationships.

Based on a short description of those three documents, one can conclude that:

\section{Before the social conflict}

Some important notions reflect the position of the GPM as to other religions before the social conflict. However, in this article, two notions can be deducted namely: other religions as the object of the church mission and as a threat or rival.

\section{- Other religions as objects of the church mission}

According to the older vision, Christianity is the only religion that teaches true and good for human beings and the world. Therefore, people must become Christians to receive salvation from God. The GPM stressed this point when the Synod Assembly decided to implement a program of evangelization for the Muslims in 1956.

Because other religions were seen as objects of conversion, the GPM never pursued a dialogue with other religions. There was no need for dialogue because the GPM did not see anything positive could be offered by a dialogue. As a consequence, the church did not recognize many influential factors created by the plurality of religion for the mission of the church. Because of this exclusive thinking, the GPM was not able to overcome problems that occurred in its relationship with other religions.

\section{- Other religions as threat or rival}

Other religions, especially Islam, were also seen as a threat to, or a rival of, Christianity as well as the church. The notion or perspective that the other religions are threat or rivals can be noticed in history. Even in the Bible, the rivalry notion has been described in more than one story. One can read the story of Cain and Abel, Esau and Jacob, Isaac and Ismael. The Bible describes as if Isaac and Ismael are two half-brothers who will not live side by side in harmony. In this story, the Bible takes its position beside Isaac than Ismael. For this rivalry, Jonathan Sack explains it very well in his book entitled Not in God's Name. He writes, "Recall that Freud and Rene Girard argued that it is not religion leads to violence. It is violence leads to religion. ... Violence is born in what he called mimetic desire. ${ }^{43}$... Girard then suggested that one of the prime sources of strife is not between father and son but between brothers: sibling rivalry." ${ }^{44}$ In history, sibling rivalry can be seen in the Abrahamic religions, such as Jews, Christians and Islam. ${ }^{45}$ However, it does not mean that sibling rivalry is the fate of Abrahamic religions. Sibling rivalry is defeated the moment we discover that we are loved by God for what we are, not for someone else. Each of us have our blessing. Brothers need not conflict. Sibling rivalry is not fate but tragic error. ${ }^{46}$

\footnotetext{
${ }^{44}$ Jonathan Sacks, Not in God's Name: Confronting Religious Violence (New York: Schocken books, 2015), 82.

${ }^{45}$ Jonathan Sacks, Not in God's Name, 82.

${ }^{46}$ Jonathan Sacks, Not in God's Name, 82-83
} 
This rivalry notion had shaped the way the church see other religions. Therefore, when facing social problems in Indonesia and the Moluccas, the church tended to act personally. If a religion addressed something wrong in society, the religion spoke and acted by itself. The negative relationship between the church and other religions, especially Islam, had been recognized by the GPM in the year 1995, but there were no efforts made to overcome it. Rather, the church remained focused on the programs related to its institutional needs. This caused the church to live 'at a distance' from the religious problems in the Moluccas. Religious relationships in the Moluccas were not good, but the GPM never tried to solve this problem. Thus, the church ran its mission while a 'hidden' tension was growing between the church (as well as Christianity as a whole) and other religions.

Reactions from Muslims during the conflict must be accepted as real expressions of this 'hidden' tension. Commenting on the relationship between Christians and Muslims in the Moluccas before the conflict, Shoelhi, who wrote a book during the social conflict, concludes: "Muslims in the Moluccas tended to maintain a distance because of the unsafe feeling they had." 47 However, he sometimes points to situations before the conflict. Reading his book, one notices that according to Shoelhi, the roots of the conflict which came to an outburst in 1999 are to be found many years before. So, the Christians used the Laskar $\mathrm{Jihad}^{48}$ only as a scapegoat.

\section{d. After the conflict}

There are two fundamental theological changing points that the GPM hold. First, a theological perspective of the GPM that other beliefs are partners of the church; and second, all believers worship to only one God.

\footnotetext{
${ }^{47}$ Shoelhi, Laskar Jihad Kambing Hitam Konflik Maluku (Jakarta: PUZAM, 2002), 4.

${ }^{48}$ Laskar Jihad is a Muslim army which came to the Moluccas during the conflict to stand beside Muslims to
}

\section{- Other religions are partners of the church}

This concept or notion reflects the GPM's belief that the church is not the only one who wants to create welfare and goodness in the lives of human beings and the world. In its Understanding of Faith, the GPM confesses that all religions have the same responsibility to humanize people. The GPM has recognized positive things in other religions, thus the church is willing to create cooperation with other religions. The GPM has recognized the negative aspects of the church's mission in the past and tried to adopt a new progressive perspective in religious relationships, which is togetherness or partnership relationships. This cooperation will reduce suspicion about a 'hidden mission' of the church (the mission of conversion).

The GPM has learnt in its history that other religions also teach their members about human dignity and their responsibility to run their lives as good neighbours to one another. Other religions have the same intention which is to create a better world for all. Other religions fight to overcome poverty, to work for justice, and to heal this wounded world. Therefore, the church has abandoned the past theological tendencies such as to control over the others, to dominate, and to become the only one true religion.

\section{- All religions point to one and the same God}

The concept that all religions point to the same God does not appear in the Understanding of Faith of the GPM when the theme "The Church and Other Religions" is discussed, but it emerges under the theme "The Kingdom of God and Religions." However, one can find its spirit in many themes related to other religions and plurality which are addressed in the Understanding of Faith. In this document, the GPM demonstrates its position in

fight against Christians. During the conflict, Christians asked the Indonesian government to remove the Laskar Jihad from the Moluccas as a way of stopping the conflict. 
understanding Christianity among other religions. Because of this concept, the tendency to understand the mission of the church as a mission of conversion no longer exists. The GPM has made a radical change since the church operated its mission long time ago within the concept of the superiority of Christianity among other religions. However, within this new concept, the GPM never discusses how the church understands Jesus Christ concerning the One God to whom all religions are pointing. This is a common tendency within religious pluralism.

Personally speaking, accepting the plurality of religions must not lead to a vague religious faith. On the contrary, this awareness must enable all religious people to learn more about their specific faith, which must, in turn, enable them as believers to respect other religions. More precisely, the plurality of religion as a reality in the life of human beings is a great opportunity to recognize, to respect and to receive the differences of each religion openly; at the same time, each religion has to maintain its specific faith and its unique, critical voice. A plurality of Religion must not cause each religion to lose its specific faith or uniqueness. Recognizing and respecting the uniqueness of each religion can be seen in the religious life of the Moluccan Muslims and the Moluccan Christians. The following part describes intereligious relation between Moluccan Muslims and the Moluccan Christians.

\section{The Religious Life of the Moluccans Shaped by the Pela}

To understand how the religious life of the Moluccans shaped by the Pela, it is beneficial to explain shortly about the Pela. Literarily, Pela means something to be finished or to be at the end. Pela is a Moluccans local culture which was performed by some people

\footnotetext{
${ }^{49}$ Rachel Iwamony, Steve Gaspersz, and Nancy Souissa, "To Embrace and Be Embraced: School Pela In Post-Conflict Ambon," Studies in Interreligious Dialogue Journal 29, no. 1 (2019), 2.
}

to overcome crisis such as war or natural disaster in which one village received assistance from other villagers. In each situation, villages declared themselves as brothers and sisters. By doing this tradition, the participants have recognized some basics obligations, such as they have to help each other, to take care of and to protect each other. In some Pela relationships, especially the ones who called Pela Darah (blood Pela), the participants are prohibited to marry each other, even though they have no biological family relationship. Beside this Pela Darah, there are some other types, such as Pela Batu Karang (Rock Pela), Pela Gandong (Womb Pela), Pela Tampa Siri (Betelbox Pela). Generally, Pela Batu Karang is another term used to refer to Pela Darah (Blood Pela) or Pela Keras (Hard Pela). ${ }^{49}$

The Pela relation influences also the religious life of its participants, especially the Moluccans Moslems and Christians in the Central Moluccas. However, this article focuses on two aspects as follows:

\section{- To accept a plurality of religion}

The participants of Pela always acknowledge that even though the residents of the two villages have different religions, they are brothers-sisters. In this sense, different religions are a fact that cannot be rejected nor ignored, so they have to respect it. ${ }^{50}$ This cultural habit has shaped their religious perspectives in seeing each other. So, in the Moluccas it is a common habit that Muslims will not afraid or doubt to help Christians to fulfil their religious obligations even in a Muslim village; Christians will also help Muslims to fulfil their religious obligations such as to pray in a Christian home.

There is an important positive value in the perspective of acceptance of the plurality of religion. The positive value is that the participants of the Pela have no feelings of

\footnotetext{
${ }^{50}$ Yola Permani Lalopua and Rachel Iwamony, "Teologi Pela: Studi Teologi Kontekstual Di Negeri Abubu Dan Negeri Tengah-Tengah," ARUMBAE: Jurnal Ilmiah Teologi Dan Studi Agama 1, no. 1 (2019): 74-85.
} 
superiority over others regarding religious life. They do not recognize the strength of their religion after seeing the weakness of other religions, but they strongly believe in their faith, while they also let others live according to their religious faith. Thus, this perspective helps religious people to have an open attitude toward the plurality of religion. Interestingly, participants of Pela noticed the benefit of the existence of a plurality of religion in their life. In their points of view, it helps them to understand and to experience their religion deeply. They find a positive impact in the existence of other religions which force them to learn more about and to have a deeper faith in their own. This argument opens the ability of religious people to see other religions positively. They do not see other religions as rivals or a threat to their religious life but accept it as a fruitful co-existence.

This religious attitude is a challenge because it requires self-examination in one's religious life. In the context of a plurality of religion, each religion tries to find the positive impact of the existence of other religions in their environment. It requires a genuine willingness to search deeply in one's own religious faith.

\section{- To take part in religious celebrations}

Taking part in other religious celebrations is a challenging act. However, it is not for the participants of a Pela and the Moluccans as a whole. For instance religious celebration in Batu Merah, ${ }^{51}$ Moslems, and Christians' Passo village. As Moslems, it is prohibited in the law of Islam to take part in a ceremony in a church; but they cannot escape this act due to their cultural obligation. However, if one examines more closely, the Christians and Muslims attended the religious ceremonies interchangeably only in certain occasions. For example, Christians attended a Muslim religious ceremony in a Mosque to show their support of the new raja, a chief of Negri Batu

\footnotetext{
${ }^{51}$ Batu Merah is a village in Ambon Island. This village has pela relation with Passo, a village in Ambon island also. These two village has pela relation which is called pela adik-kakak.
}

Merah. Muslims attended Christian's religious ceremony in a Church to show their happiness of celebrating a century's birthday of the church in Negri Passo. This does not mean that Moluccan Muslims and Moluccan Christians are performing a mixed religion. Moluccan Muslims remain Islam; so do the Moluccan Christians. They just show togetherness in running each religious life.

In addition, Moluccan Christians commonly taking part in preparing an MTQ event, ${ }^{52}$ as it was in 2015, is also a manner of sharing the Muslims' joy of that celebration; as is the Moluccan Muslims partaking in preparations and participating in the opening ceremony of the Assembly of the Communion of Churches in Indonesia or Persekutuan Gereja-Gereja Indonesia (abbreviated PGI) in Ambon, the Moluccas, in 1984. Thus, both Moluccan Christians and Moluccan Muslims tried to share their happiness, as well as their pain throughout the time of religious event celebrations. Those practices reflect the theological perspectives of Muslims and Christians that a religious celebration is a time of gathering together. A religious celebration is an occasion of supporting each other in daily life as well as experiencing their religion. A religious celebration is a bridge-building moment through which religious people experience that religion must not create a gap.

Religious life shaped by the Pela offers a different perspective in seeing other religion. Furthermore, it also criticizes theological perspectives which tend to exclude other religion and helps to overcome rivalry between Muslims and Christians as the GPM held in the beginning. By the Pela, Moluccan Muslims and Christians learn that religion does not separate human beings. It teaches also Moluccan that religious triumphalism against values of all religions. In other words, Pela principally confirms the core doctrine of all religion which is to love and to show

\footnotetext{
${ }^{52}$ Rachel Iwamony, "Toleransi Dalam Persepktif Orang Maluku," in Costly Tolerance, ed. Syamsudin (Yogyakarta: CRCS, 2018), 235.
} 
compassion to all. It is what people call real-life dialogue. ${ }^{53}$ However, in performing this real live dialogue, the Moluccan Muslims and Christians must aware that "dialogue is a willingness to talk to and to know each other without getting into a mixed religion." 54

\section{CONCLUSIONS}

Exploration of the theological transformation of the GPM in seeing other religions opens some important notions, namely:First, since the GPM came into its existence, the church runs its mission in the concept that Christianity is the only true religion, so the mission of the church is to convert as many as people including religious others. Based on this theological point of view, the GPM tended not to embrace other religious people. Besides, the church pointed to religious others as a threat and a rival.

Second, after the Moluccans experienced a serious social religious conflict in 1999 and 2004, the church develops fundamental theological changing perspectives. Other religions have been recognized as a partner of the church and believe in the same God. It means that for the GPM, Christianity is not the only one true religion anymore. This theological transformation is also shaped by the Moluccans local culture such as Pela, which enables the Moluccans Muslims and Christians to live side by side in harmony, to share their joy in religious event celebrations, and to support each other to live their religious obligations.

Third, this theological transformation is a big step of the GPM. However, the church should not come to the safe zone and stop working on religious reconciliation. The church still has a responsibility to work together with religious other to overcome religious conflict in social life.

\footnotetext{
${ }^{53}$ Stephanus Turibius Rahmat, "Dialog Antropologis Antaragama Dengan Spiritualitas Passing Over," Wawasan: Jurnal Ilmiah Agama Dan Sosial Budaya 2, no. 2 (2017): 181-198.
}

\section{REFERENCES}

Abdi, Alfian Putra. "Duduk Perkara Penolakan Pembangunan Pura Di Bekasi." Tirto. Accessed May 7, 2019. https://tirto.id/dJez.

Aritonang, Jan Sihar, and Karel Adriaan Steenbrink. A History of Christianity in Indonesia. Leiden: Brill, 2008.

Bartels, Dieter. Di Bawah Naungan Gunung Nunusaku: Muslim-Kristen Hidup Berdampingan Di Maluku Tengah. Jakarta: Yayasan Obor, 2017.

End, Th. van den. Ragi Carita 1. Jakarta: BPK Gunung Mulia, 2001.

End, Th van den, and J. Weitjens. Ragi Carita 2:Sejarah Gereja Di Indonesia 1860-an Sekarang. Jakarta: BPK Gunung Mulia, 1993.

Enklaar, Ido Hendricus, and Joseph Kam. Apostel Der Molukken. Zoetermeer: Boekencentrum, 1963.

Ismail, Arifudin. Prahara Yang Terselubung. Yogyakarta: Trussmedia Grafika, 2017.

Iwamony, Rachel. "Majority versus Minority." In International Conference on Religion and Public Civilization (ICRPC 2018). Atlantis Press, 2019.

—. "Toleransi Dalam Persepktif Orang Maluku." In Costly Tolerance, edited by Syamsudin. Yogyakarta: CRCS, 2018.

Iwamony, Rachel, Steve Gaspersz, and Nancy Souissa. "To Embrace and Be Embraced: School Pela In Post-Conflict Ambon." Studies in Interreligious Dialogue Journal 29, no. 1 (2019).

Iwamony, Rachel, and Tri Astuti Relmasira. "Rekonsiliasi Sebagai Proses Bersama Menyembuhkan Luka Sejarah Islam Kristen Di Kota Ambon." Religió: Jurnal Studi Agama-Agama 7, no. 1 (2017): 1-27.

Jamaludin, Adon Nasrullah. "Konflik Dan Integrasi Pendirian Rumah Ibadah Di Kota Bekasi." Jurnal Socio-Politica 8, no. 2 (2018): 227-38.

Jong, C G F de, and M van Selm. "Verslag van

\footnotetext{
${ }^{54}$ Markus Solo Kewuta, trans., Muslim Bertanya Kristen Menjawab (Jakarta: Kompas Gramedia, 2017), xxxii.
} 
Een Reis Naar de Zuidwester-En Zuidooster-Eilanden (Zuid-Molukken) Door Joseph Kam (1825)." Documentatieblad Voor de Geschiedenis van de Nederlandse Zending En Overzeese Kerken 6 (1999): 4778.

Kewuta, Markus Solo, trans. Muslim Bertanya Kristen Menjawab. Jakarta: Kompas Gramedia, 2017.

Kraemer, Hendrik. From Missionfield to Independent Church: Report on a Decisive Decade in the Growth of Indigenous Churches in Indonesia. Zoetermeer: Boekencentrum, 1958.

Lalopua, Yola Permani, and Rachel Iwamony. "Teologi Pela: Studi Teologi Kontekstual Di Negeri Abubu Dan Negeri Tengah-Tengah." ARUMBAE: Jurnal Ilmiah Teologi Dan Studi Agama 1, no. 1 (2019): 74-85.

Magnis-Suseno, Frans. Iman Dan Hati Nurani. Jakarta: Yayasan Obor, 2014.

Neill, Stephen. Colonialism and Christian Mission. London: Lutterworth Press, 1966.

Patty, Verry. "Molukse Theologie in Nederland: Agama Nunusaku En Bekering." Vrije Universiteit, 2018.

Prabowo, Haris. "Duduk Perkara Penolakan Gereja GKI Di Jagakarsa, Jakarta Selatan." Tirto. Accessed May 7, 2019. https://tirto.id/duduk-perkara-penolakangereja-gki-di-jagakarsa-jakarta-selatandeoZ.

Rahmat, Stephanus Turibius. "Dialog Antropologis Antaragama Dengan Spiritualitas Passing Over." Wawasan: Jurnal Ilmiah Agama Dan Sosial Budaya 2, no. 2 (2017): 181-98.

Rosyid, Moh. "Peredam Konflik Agama: Studi Analisis Penyelesaian Di Tolikara Papua
2015." Afkaruna: Indonesian Interdisciplinary Journal of Islamic Studies 13, no. 1 (2017): 48-81.

Sabri, Muhammad, and Siti Musyahidah. "Agama Mainstream, Nalar Negara Dan Paham Lintas Iman: Menimbang Philosophia Perennis." Jurnal Diskursus Islam 3, no. 1 (2015): 73-101.

Sacks, Jonathan. Not in God's Name: Confronting Religious Violence. New York: Schocken books, 2015.

Shoelhi. Laskar Jihad Kambing Hitam Konflik Maluku. Jakarta: PUZAM, 2002.

Sholih, Mufti. "Di Balik Polemik Penolakan Menara Masjid Di Papua." Tirto. Accessed May 7, 2019. https://tirto.id/di-balikpolemik-penolakan-menara-masjid-dipapua-cGrd.

Sinode Gereja Protestan Maluku. Ketetapan Sinode Gereja Protestan Maluku, No. 9/SND/ke-35/ (2005).

St Aisyah, B M. "Konflik Sosial Dalam Hubungan Antar Umat Beragama." Jurnal Dakwah Tabligh 15, no. 2 (2014): 189-208.

Steenbrink, Karel. Catholics in Indonesia, 1808-1942: A Documented History. Volume 2: The Spectacular Growth of a Self Confident Minority, 1903-1942. Leiden: Brill, 2007.

Tempo.co. "Massa Berunjuk Rasa Tolak Pembangunan Gereja Santa Clara Bekasi." Tempo.co. Accessed May 7, 2019. https://metro.tempo.co/read/859291/massaberunjuk-rasa-tolak-pembangunan-gerejasanta-clara-bekasi.

The GPM. Tata Gereja Dan PeraturanPeraturan Pokok Gereja Protestan Maluku. Ambon: The GPM, 1990. 